JURNAL KEPENDUDUKAN INDONESIA

\author{
p-ISSN : 1907-2902 (Print) \\ e-ISSN : 2502-8537 (Online)
}

\title{
IMPLEMENTASI KEBIJAKAN KESEHATAN REPRODUKSI DI INDONESIA: SEBELUM DAN SESUDAH REFORMASI
}

\section{IMPLEMENTATION OF REPRODUCTIVE HEALTH POLICY IN INDONESIA: BEFORE AND AFTER THE REFORM ERA}

\author{
Zainal Fatoni, Yuly Astuti, Sari Seftiani, \\ Augustina Situmorang, Widayatun, dan Sri Sunarti Purwaningsih \\ Pusat Penelitian Kependudukan - Lembaga Ilmu Pengetahuan Indonesia \\ Korespondensi Penulis: zainalfatonilipi@gmail.com
}

\begin{abstract}
Policy on reproductive health is one of the essential determinant to address the goals of population and health development in Indonesia. Maternal Mortality Ratio (MMR), teenage marriage, and Total Fertility Rate (TFR) are among the indicators that show the important role of reproductive health policy. This article discusses the progress of reproductive health policy implementation in Indonesia and its implication to early marriage, $T F R$, and MMR. Data used in this paper are mainly derived through desk studies from previous research conducted by the Research Center for Population - Indonesian Institute of Sciences. The studies consist of reproductive health policy and regional autonomy (2000-2005), BKKBN's decentralization (2005), HIV/AIDS in border areas (2006-2009), and the implementation of integrated reproductive health services in primary health care (2007). Desk reviews are also used to analyze current studies from LIPI that are related to these issues.
\end{abstract}

LIPI's studies showed that there is a gap between the implementation of reproductive health policy at the global and national level with the district level. The implementation of reproductive health services are not yet integrated as it is less popular than adolescent reproductive health policy. Policy priorities for relevant stakeholders have not been implemented synergically. The implementation of decentralization policy in early 2000's created various commitments from the local government in prioritizing reproductive health programs. $B K K B N$ 's decentralization, for example, has affected not only the structure of its institution at district level, but also the function of the family planning facilitator at village level. Meanwhile, pilot project implementation on the integrated essential reproductive health services in primary health cares that has significant contribution also faced uncertainty in terms of its continuation. Hence, this article suggests the importance of synergizing reproductive health policy at the global, national, and district level to meet the appropriate situation and needs at the local context. Otherwise, teenage marriage, TFR, and MMR as well as other population issues will be further overlooked.

Keywords: Population Dynamics, Reproductive Health, Policy, Regional Autonomy

\begin{abstract}
Abstrak
Kebijakan kesehatan reproduksi merupakan salah satu determinan penting pencapaian tujuan pembangunan kependudukan dan kesehatan di Indonesia. Angka Kematian Ibu (AKI), perkawinan usia dini, dan angka fertilitas total (Total Fertility Rate atau TFR) merupakan sebagian indikator yang menunjukkan pentingnya peran kebijakan kesehatan reproduksi tersebut. Tulisan ini mengkaji perjalanan implementasi kebijakan kesehatan reproduksi di Indonesia serta implikasinya terhadap perkawinan usia muda, TFR, dan AKI. Data dan informasi yang digunakan dalam tulisan ini terutama berdasarkan hasil review terhadap berbagai studi yang dilakukan tim peneliti Pusat Penelitian (P2) Kependudukan LIPI. Hasil kajian P2 Kependudukan LIPI termasuk: kebijakan kesehatan reproduksi dan otonomi daerah (2000-2005), desentralisasi BKKBN (2005), HIV/AIDS di wilayah perbatasan (2006-2009), serta implementasi Pelayanan Kesehatan Reproduksi Esensial Terpadu (PKRE Terpadu) di puskesmas (2007). Selain itu, metode desk review dilakukan untuk mempertajam analisis hasil studi P2 Kependudukan LIPI dalam konteks kekinian.
\end{abstract}

Hasil kajian P2 Kependudukan LIPI menunjukkan 'terputusnya' kebijakan kesehatan reproduksi di tingkat global dan nasional dengan kebijakan yang sama di tingkat daerah (kabupaten/kota). Pelayanan kesehatan reproduksi belum dipahami secara integral, masih dianggap 'identik' dengan kesehatan reproduksi remaja. Prioritas kebijakan pada stakeholders terkait juga belum dijalankan secara sinergis. Penerapan kebijakan otonomi daerah pada awal tahun 2000-an berakibat pada bervariasinya komitmen daerah untuk memprioritaskan kesehatan reproduksi. Desentralisasi BKKBN, misalnya, berdampak pada tercerai-berainya nomenklatur kelembagaan di tingkat kabupaten/kota serta tidak berfungsinya lagi ujung tombak petugas lapangan (PLKB). Sementara itu, uji coba implementasi PKRE Terpadu di puskesmas yang berdampak nyata juga menghadapi permasalahan keberlanjutan program yang tidak terjamin. Oleh karena itu, tulisan ini merekomendasikan perlunya upaya memadukan kembali kebijakan kesehatan reproduksi di tingkat global, nasional, dan daerah. Jika tidak, perkawinan usia muda, TFR, AKI, serta isu-isu kependudukan strategis lainnya akan semakin terabaikan.

Kata Kunci: Dinamika Penduduk, Kesehatan Reproduksi, Kebijakan, Otonomi Daerah 


\section{PENDAHULUAN}

Indonesia masih menghadapi berbagai permasalahan kependudukan dan kesehatan hingga saat ini. Angka Kematian Ibu (AKI), perkawinan usia dini, serta angka fertilitas total (Total Fertility Rate atau TFR) merupakan sebagian indikator yang menunjukkan pentingnya peran kebijakan kesehatan reproduksi. Terkait dengan pencapaian Tujuan Pembangunan Milenium (Millenium Development Goals atau MDGs), misalnya, AKI merupakan salah satu indikator yang diperkirakan tidak berhasil mencapai target yang ditetapkan. Indikator AKI telah mengalami penurunan dalam beberapa dekade terakhir, dari 334 kasus kematian per 1.000 kelahiran hidup (Survei Demografi dan Kesehatan Indonesia atau SDKI 1997) menurun menjadi 307 kasus kematian per 1.000 kelahiran hidup (SDKI 2002/2003), serta selanjutnya mencapai 228 kasus kematian per 1.000 kelahiran hidup (SDKI 2007). Namun demikian, data terakhir menunjukkan indikator AKI justru kembali meningkat menjadi 359 per 100.000 kelahiran hidup berdasarkan hasil SDKI 2012. Memburuknya indikator AKI ini menarik untuk dikaji, padahal data SDKI 2012 menunjukkan 75 persen persalinan telah ditolong oleh tenaga kesehatan. Sumber lain menyebutkan penyebab masih tingginya AKI, termasuk aborsi tidak aman, baik di perdesaan maupun di perkotaan (Shewprasad dan Habsjah, 2014).

Menariknya, indikator AKI yang masih tinggi juga dipengaruhi oleh penyebab tidak langsung, yakni fenomena perkawinan usia dini yang meningkat serta hubungan seks pranikah di kalangan remaja yang semakin tinggi. Data SDKI 2012 menunjukkan masih terdapat sekitar 13 persen remaja perempuan berusia 15-19 tahun yang telah menikah, separuh di antara mereka telah memiliki setidaknya satu anak pada rentang usia tersebut. Perkawinan di usia muda ini akan memberikan sumbangan terhadap tingginya kelahiran. Meskipun persentasenya relatif kecil, fenomena ini perlu mendapat perhatian karena cenderung banyak kasus perkawinan usia dini tidak tercatat dengan baik (underreported). Selain itu, masih terjadi perkawinan di usia kurang dari 14 tahun, bahkan terjadi di daerah perkotaan yang umumnya akses dan informasinya lebih banyak dan mudah diperoleh (Wahyuni dan Rahmadewi, 2011).

Permasalahan kependudukan lainnya adalah angka fertilitas total (Total Fertility Rate atau TFR) yang mengalami stagnasi. Berdasarkan hasil tiga SDKI terakhir (2002, 2007, dan 2012), TFR berada pada angka 2,6 dan masih jauh dari target pencapaian RPJMN 2009-2014 pada angka 2,1. Beberapa faktor penyebab kenaikan TFR antara lain masih banyaknya pasangan usia subur (PUS) yang tidak ber-KB, laju pertumbuhan penduduk yang tinggi serta tingginya unmet need. Bila melihat kompleksnya permasalahan kependudukan yang dihadapi, diperkirakan Indonesia mengalami kegagalan dalam mencapai sebagian tujuan pembangunan nasional (RPJMN 2009-2014) maupun MDGs 2015.

Berbagai studi dan literatur menunjukkan kompleksitas permasalahan kependudukan di Indonesia. Hasil kajian UNDP (2011) menyebutkan bahwa kesehatan ibu dipengaruhi oleh faktor-faktor sosial penentu kesehatan, seperti kemiskinan, pendidikan, pekerjaan, akses ke perawatan kesehatan, status kesehatan, dan ketidaksetaraan jender akibat nilai-nilai sosial budaya di masyarakat. Isu pernikahan usia dini dan kehamilan remaja juga tidak lepas dari persoalan kemiskinan, kekerasan seksual, minimnya akses pendidikan dan layanan kesehatan reproduksi, hingga penerapan kebijakan nasional yang belum optimal (http://www.cpps.or.id/content/isu-kehamilanremaja-tantangan-bagi-indonesia).

Kebijakan kesehatan reproduksi merupakan salah satu determinan penting pencapaian tujuan pembangunan kesehatan di Indonesia, termasuk dalam mengatasi berbagai permasalahan kependudukan dan kesehatan. Sebagaimana hasil kesepakatan Konferensi Kependudukan dan Pembangunan Sedunia (ICPD) 1994 di Cairo yang telah diratifikasi Indonesia, terdapat perubahan paradigma dalam pengelolaan masalah kependudukan dan pembangunan, dari pendekatan pengendalian populasi dan penurunan fertilitas menjadi pendekatan yang berfokus pada hak reproduksi dan kesehatan reproduksi perorangan (United Nations, 1995). Sayangnya, berbagai tantangan dihadapi berkaitan dengan implementasi kebijakan kesehatan reproduksi paradigma baru di Indonesia, termasuk momentum pelaksanaannya yang hampir bersamaan dengan proses reformasi dan penerapan kebijakan otonomi daerah.

Tulisan ini mengkaji perjalanan implementasi kebijakan kesehatan reproduksi di Indonesia sebelum dan sesudah reformasi. Era reformasi 1998 dalam tulisan ini lebih dilihat sebagai momentum yang berada di antara tahun 1994 (sebelum reformasi) yang ditandai dengan dihasilkannya kesepakatan ICPD Cairo dan tahun 2000 (sesudah reformasi) yang menjadi tonggak sistem pemerintahan yang didesentralisasi melalui penerapan otonomi daerah. Dalam beberapa bagian tulisan, deskripsi mengenai implementasi kebijakan kesehatan reproduksi tersebut dikaitkan dengan persoalan masih tingginya AKI dan perkawinan usia dini serta masih stagnannya indikator TFR. Data dan informasi yang digunakan dalam 
tulisan ini terutama berdasarkan hasil review terhadap berbagai studi kesehatan reproduksi yang dilakukan tim peneliti Pusat Penelitian (P2) Kependudukan LIPI. Hasil kajian P2 Kependudukan LIPI termasuk: kebijakan kesehatan reproduksi dan otonomi daerah (2000-2005), desentralisasi BKKBN (2005), HIV/AIDS di wilayah perbatasan (2006-2009), serta implementasi Pelayanan Kesehatan Reproduksi Esensial Terpadu (PKRE Terpadu) di puskesmas (2007). Selain itu, metode desk review dilakukan untuk mempertajam analisis hasil studi P2 Kependudukan LIPI dalam konteks kekinian, termasuk berbagai peraturan dan kebijakan yang relevan dengan tulisan ini.

\section{KESEHATAN REPRODUKSI PARADIGMA BARU PASCA ICPD CAIRO 1994}

The International Conference on Population and Development (ICPD) di Cairo tahun 1994 diakui oleh para ahli kependudukan sedunia sebagai tonggak perubahan dalam melihat permasalahan kependudukan. Konferensi tersebut menghasilkan suatu kesepakatan mengenai pendekatan yang menekankan kaitan integral antara masalah kependudukan dan pembangunan yang berfokus pada terpenuhinya kebutuhan dasar individu, baik laki-laki maupun perempuan, bukan lagi sekedar pencapaian target-target demografis (United Nations, 1995; Shalev, 1998).

Paradigma baru kesehatan reproduksi ${ }^{1}$ menurut kesepakatan ICPD Cairo 1994 menekankan bahwa kesehatan reproduksi merupakan hak asasi manusia. Pemenuhan hak-hak dasar kesehatan reproduksi meliputi hak setiap orang (baik pasangan maupun individu) dalam memutuskan secara bebas dan bertanggungjawab terkait jumlah, jarak, dan waktu memiliki anak. Setiap orang, baik laki-laki maupun perempuan, juga berhak untuk mendapatkan informasi dan pelayanan kesehatan reproduksi yang berkualitas. Hal ini termasuk akses informasi mengenai cara-cara kontrasepsi sehingga dapat memilih cara yang tepat dan disukai tanpa adanya paksaan. Selain itu, hak untuk mendapatkan pelayanan kesehatan reproduksi

\footnotetext{
${ }^{1}$ Definisi kesehatan reproduksi menurut ICPD Cairo pada tahun 1994 adalah: "a state of complete physical, mental and social wellbeing and not merely the absence of disease or infirmity, in all matters relating to the reproductive system and to its functions and processes. People are able to have a satisfying and safe sex life and they have the capability to reproduce and the freedom to decide if, when and how often to do so. Men and women have the right to be informed and have access to safe, effective, affordable fertility, which are not against the law, as well as access to appropriate health-care services for safe pregnancy and childbirth, and have the best chance of having a healthy infant (United Nations, 1995: 31).
}

lainnya, seperti pelayanan antenatal, nifas, pelayanan bagi anak, serta kesehatan reproduksi remaja perlu di jamin (United Nations, 1995).

Secara rinci, kesepakatan ICPD Cairo menuntut beberapa perubahan konseptual yang berkaitan dengan kesehatan reproduksi (Raharjo dkk, 2002), antara lain:

- Diakuinya kesehatan reproduksi, hak reproduksi dan pemberdayaan perempuan sebagai prioritas dalam pembangunan;

- Kesehatan seksual dan kesehatan reproduksi harus dilihat dalam konteks yang lebih luas, bukan hanya sebagai isu demografis dan $\mathrm{KB}$ atau kesehatan ibu;

- Isu kesehatan seksual dan kesehatan reproduksi merupakan bagian integral dari pembangunan dan hak asasi manusia, termasuk didalamnya keperluan dasar kesehatan yang lebih luas, misalnya hak perempuan dalam mengontrol dan mengambil keputusan mengenai kesehatan seksual dan kesehatan reproduksinya;

- Kebijakan kependudukan dan program KB harus berdasarkan atas sukarela, tidak ada pemaksaanpemaksaan utamanya terhadap perempuan, yang bertentangan dengan hak asasi manusia. Selain itu juga tersedia pilihan-pilihan dan informasi yang cukup mengenai metode maupun alat kontrasepsi.

Indonesia telah menetapkan komitmennya untuk meratifikasi kesepakatan ICPD Cairo 1994. Komitmen ini dituangkan melalui Lokakarya Nasional Kesehatan Reproduksi di Jakarta pada Mei 1996, yang melibatkan seluruh sektor terkait, LSM termasuk organisasi wanita, organisasi profesi, universitas, dan lembaga donor. Dalam lokakarya tersebut telah disepakati definisi kesehatan reproduksi, yaitu suatu keadaan sejahtera fisik, mental, dan sosial secara utuh, tidak semata-mata bebas dari penyakit atau kecacatan dalam semua hal yang berkaitan dengan sistem reproduksi, serta fungsi dan prosesnya. Sebagai tindak lanjut, tercapai kesepakatan untuk membentuk Komisi Kesehatan Reproduksi dan Komisi Penanggulangan AIDS (KPA) berdasarkan Surat Keputusan (SK) Menteri Kesehatan Nomor 433/MENKES/SK/V/1998 di tingkat nasional dan provinsi. Komnas Kesehatan Reproduksi dibagi ke dalam empat gugus tugas yang disesuaikan dengan program prioritas nasional, yaitu safe motherhood, $\mathrm{KB}$, kesehatan reproduksi remaja, dan kesehatan reproduksi bagi penduduk usia lanjut.

Pemerintah Indonesia juga telah berupaya merubah konsep dan strategi pelayanan kesehatan reproduksi dan KB yang ada selama ini. Sesuai dengan kondisi dan situasi di Indonesia, dipilih lima prioritas bidang kesehatan reproduksi yang meliputi empat esensi dan 
lima komprehensif. Empat komponen Pelayanan Kesehatan Reproduksi Esensial (PKRE) tersebut adalah (1) Kesehatan Ibu dan Anak (KIA), (2) Keluarga Berencana (KB), (3) Kesehatan Reproduksi Remaja (KRR), (4) Pencegahan dan penanggulangan IMS termasuk HIV/AIDS. Jika PKRE ditambah komponen kelima, yaitu pelayanan kesehatan reproduksi usia lanjut, maka pelayanan tersebut menjadi Pelayanan Kesehatan Reproduksi Komprehensif (PKRK).

Beberapa kebijakan yang berkaitan dengan kesehatan reproduksi telah disusun dan diimplementasikan, meskipun masih banyak aspek atau isu yang belum mendapat perhatian secara penuh. Berbagai faktor diduga ikut berpengaruh terhadap upaya peningkatan perhatian terhadap isu-isu yang berhubungan dengan kebijakan mengenai kesehatan reproduksi. Hasil kajian P2 Kependudukan LIPI menunjukkan isu kesehatan reproduksi tidak bisa dipahami hanya sebagai masalah kesehatan saja, tetapi juga sangat erat kaitannya dengan aspek lainnya, termasuk sosial, budaya, politik, dan agama. Dari sisi eksternal, keterpurukan ekonomi dan munculnya berbagai permasalahan sosial dan politik di Indonesia pada momentum reformasi 1998 serta pemberlakuan kebijakan baru mengenai otonomi daerah pada awal tahun 2000-an membuat implementasi kebijakan kesehatan reproduksi paradigma baru di Indonesia menjadi semakin kompleks. Studi sebelumnya di negara lain juga menunjukkan tidak mudahnya memprioritaskan kesehatan reproduksi di era desentralisasi, termasuk berkaitan dengan faktor kepemimpinan dan prioritas daerah (Diop dkk, 2000).

\section{IMPLEMENTASI KEBIJAKAN KESEHAT-AN REPRODUKSI PARADIGMA BARU DI INDONESIA: PELUANG DAN TANTANGAN}

Sebagaimana disinggung sebelumnya, isu kesehatan reproduksi di Indonesia sangat kompleks, tidak hanya menyangkut aspek kesehatan, tetapi juga berkaitan erat dengan persoalan lainnya, termasuk budaya, politik, dan agama. Tulisan ini mengidentifikasi setidaknya ada empat peluang dan tantangan yang dihadapi berkaitan dengan implementasi kebijakan kesehatan reproduksi paradigma baru di Indonesia. Keempat tantangan tersebut berkaitan erat dengan faktor piranti legal, faktor pemahaman stakeholders, faktor kebijakan otonomi daerah termasuk prioritas pembangunan di tingkat pusat dan daerah, serta faktor kelembagaan (institusi pelaksana).

\section{- Piranti legal (perundang-undangan)}

Berbagai permasalahan terkait kesehatan reproduksi masih menjadi tantangan tersendiri bagi Indonesia. Hal ini dikarenakan masih adanya piranti legal (perundangundangan) di tingkat nasional yang belum optimal dan kondusif dalam mengadopsi kesehatan reproduksi paradigma baru, khususnya berkaitan dengan pemenuhan hak reproduksi setiap individu. Berkaitan dengan masih maraknya perkawinan usia dini, misalnya, masih ada ketidakselarasan antara UndangUndang (UU) Perkawinan Nomor 1 tahun 1974 dengan standar hak asasi manusia dalam konvensi internasional seperti CEDAW (Convention on the Elimination of All Forms of Discrimination against Women). Batas minimum usia menikah berdasarkan kesepakatan di tingkat internasional adalah 18 tahun, sementara UU di Indonesia masih memberlakukan 16 tahun bagi perempuan dan 19 tahun bagi laki-laki. Permohonan merevisi pasal terkait batas usia menikah (pasal 7) menjadi 18 tahun, hingga saat ini masih dalam proses di Mahkamah Konstitusi (Kompas, 2014). Meskipun data resmi menunjukkan median usia perempuan menikah meningkat dari 19,8 tahun pada 2007 menjadi 20,1 tahun pada 2012, sebagaimana dibahas pada bagian awal tulisan ini, banyak kasus perkawinan usia dini yang tidak terdata dengan baik (under reported). Tidak hanya mengurangi kejadian perkawinan usia dini, pendewasaan usia perkawinan pada dasarnya juga diharapkan dapat berkontribusi tidak langsung menurunkan TFR dan AKI di Indonesia.

Beberapa perundang-undangan juga dirasakan masih sangat tidak mendukung situasi kelompok penduduk tertentu, seperti remaja dan penduduk dewasa lajang. UU Kependudukan dan Kesejahteraan Keluarga Nomor 52 Tahun 2009 menyebutkan bahwa pelayanan kesehatan reproduksi dari pemerintah hanya disediakan untuk mereka yang secara legal sudah menikah. Konsekuensi dari tidak adanya kebijakan kesehatan reproduksi bagi penduduk dewasa lajang dan remaja menjadikan kelompok tersebut berisiko tinggi terhadap permasalahan kesehatan reproduksi, termasuk penyakit menular seksual, termasuk HIV dan AIDS, kehamilan sebelum menikah serta aborsi. Hasil survei The Greater Jakarta Transition to Adulthood Study yang dilakukan pada 2010 menyebutkan 14 persen laki-laki dan 7 persen perempuan dari total 3.600 responden usia 20-34 tahun berhubungan seks sebelum menikah. Data juga menunjukkan bahwa dua pertiga dari keseluruhan responden yang melakukan hubungan seksual pranikah tidak menggunakan kondom untuk pencegahan penyakit atau bentuk lain dari KB untuk menghindari kehamilan (Utomo dkk, 2012). 
Peraturan Pemerintah (PP) Nomor 61 Tahun 2014 tentang Kesehatan Reproduksi sudah menjelaskan bentuk pelayanan kesehatan reproduksi remaja secara terperinci. Namun, kuatnya norma-norma agama dan sosial menyebabkan promosi pelayanan kesehatan reproduksi untuk remaja dipandang sebagai hal yang sensitif. Hal ini dikarenakan masih adanya anggapan bahwa pendidikan kesehatan reproduksi akan meningkatkan kegiatan seksual kelompok usia remaja. Pendidikan kesehatan reproduksi yang dimasukkan dalam muatan lokal, seperti mata pelajaran Pendidikan Jasmani dan Kesehatan, Ilmu Pengetahuan Alam, Ilmu Pengetahuan Sosial atau pendidikan agama sekalipun masih banyak ditentang oleh orang tua murid maupun pemuka agama (Utomo dkk, 2012). Akses informasi mengenai kesehatan reproduksi remaja di tingkat Puskesmas belum tersedia di semua wilayah. Hal ini disebabkan karena model pelayanan bagi mereka sangat bergantung pada inisiatif dan komitmen dari kepala Puskesmas dan pimpinan daerah. Dengan demikian, meskipun Indonesia telah meratifikasi perjanjian-perjanjian internasional untuk pelayanan dan hak-hak kesehatan reproduksi seksual, komitmen internasional pemerintah dalam mendukung hak tersebut untuk semua warganya belum sepenuhnya diwujudkan.

Selain itu, pemberlakuan PP Nomor 61 Tahun 2014 itu sendiri masih menjadi kontroversi di sejumlah kalangan terkait dengan beberapa pasal yang mengatur mengenai aborsi. Meskipun PP tersebut mengatur secara ketat bahwa aborsi diperbolehkan karena kedaruratan medis atau kehamilan akibat perkosaan, namun tindakan tersebut dianggap legal dan sama saja dengan melakukan pembunuhan. Padahal, klausul terkait aborsi untuk kasus darurat medis dan perkosaan mensyaratkan pembuktian dari tim ahli dan hanya dapat dilakukan pada usia kehamilan maksimal 40 hari dihitung sejak hari pertama haid terakhir. Aborsi juga hanya dapat dilakukan dengan persetujuan perempuan hamil, serta diikuti dengan pemberian konseling sebelum dan sesudah aborsi. Oleh karena itu, kebijakan dalam PP tersebut harus dilihat secara komprehensif sehingga hak kesehatan bagi perempuan dapat terpenuhi.

\section{- Pemahaman stakeholders}

Konsep kesehatan reproduksi paradigma baru belum sepenuhnya mendapatkan respons (prioritas) dan pemahaman yang utuh di daerah. Hal ini antara lain disebabkan oleh mengakarnya konsep kesehatan reproduksi paradigma lama yang lebih diartikan sebagai program $\mathrm{KB}$ yang bertujuan untuk menurunkan fertilitas. Sebagian stakeholders juga masih menyamakan kesehatan reproduksi paradigma baru dengan program KIA yang selama ini berjalan, belum melihat KIA sebagai salah satu bagian yang utuh dan terkait dengan program kesehatan reproduksi lainnya. Stakeholders lainnya, terutama petugas puskesmas, tidak jarang memahami kesehatan reproduksi identik dengan kesehatan reproduksi remaja yang belum menjadi prioritas program di puskesmas.

Program kesehatan reproduksi menyangkut beberapa aspek baik yang terkait dengan aspek medis maupun aspek sosial-budaya, politik dan agama. Sebagian stakeholders, termasuk tokoh agama dan tokoh politik (anggota dewan), sebenarnya telah memiliki pemahaman individu yang cukup baik mengenai konsep kesehatan reproduksi paradigma baru. Mereka juga secara pribadi menyatakan setuju dengan kebijakan berkaitan dengan isu-isu yang masih sensitif di masyarakat, seperti promosi kondom dalam rangka pencegahan HIV/AIDS dan tindakan aborsi dengan alasan kedaruratan medis. Namun demikian, pemahaman individu yang sudah cukup baik tersebut seringkali tidak bisa 'dikomunikasikan' ke masyarakat luas dengan berbagai pertimbangan, seperti stigma negatif di masyarakat dan kepentingan untuk mendapatkan dukungan konstituen.

Program Aksi ICPD menekankan pentingnya memperhatikan perspektif gender dalam setiap kebijakan mulai dari perencanaan sampai dengan monitoring dan evaluasi. Pada kenyataannya, pentingnya memasukkan isu gender dalam kesehatan reproduksi belum sepenuhnya dipahami. Beberapa program yang ada masih menjadikan perempuan sebagai obyek semata. Dalam program KB, misalnya, lebih dari 90 persen targetnya adalah untuk akseptor perempuan. Lebih spesifik lagi target itu hanya ditujukan bagi perempuan yang bersuami, sehingga keperluan pelayanan kesehatan reproduksi yang juga dibutuhkan oleh perempuan lajang, remaja, dan perempuan tua luput dari sasaran. Rendahnya keikutsertaan suami/laki-laki dalam program KB mengindikasikan bahwa perempuan masih merupakan target sasaran dari program KB.

Pemberian pelayanan secara integratif, berkualitas, dan memperhatikan kepuasan pasien merupakan bentuk pelayanan yang sesuai dengan paradigma baru kesehatan reproduksi. Uji coba implementasi program PKRE Terpadu di tingkat puskesmas telah menunjukkan dampak nyata, termasuk berkaitan dengan pemahaman petugas kesehatan dan stakeholders terkait mengenai pentingnya keterpaduan kesehatan reproduksi demi meningkatkan kualitas 
pelayanan dan kepuasan klien. Sayangnya, keberhasilan program PKRE Terpadu di puskesmas binaan tersebut tidak didukung dengan komitmen untuk memperluas program serupa di wilayah-wilayah puskesmas lainnya.

\section{- Prioritas pembangunan di tingkat pusat dan daerah}

Pemberlakuan otonomi daerah memberikan kewenangan kepada daerah (kabupaten/kota) untuk mengatur dan mengurus kepentingan masyarakat setempat menurut prakarsa sendiri berdasarkan aspirasi masyarakat sesuai dengan peraturan perundangan. Implementasi otonomi daerah ini seharusnya memberikan peluang bagi daerah untuk menentukan yang terbaik bagi daerahnya serta memberikan peluang partipasi masyarakat yang seluas-luasnya (Diop dkk, 2000). Namun dalam praktiknya, pemberlakuan otonomi daerah banyak berdampak terhadap program pemerintah.

Euforia otonomi daerah cenderung tidak memandang penting terhadap beberapa program yang berasal dari pusat, baik program yang sudah berjalan, apalagi program baru (tahun 2000-an) seperti kesehatan reproduksi. Ada kecenderungan program-program sosial semacam program kesehatan reproduksi tidak dianggap penting dibandingkan program-program yang menghasilkan uang, seperti program berbagai macam pajak atau program lain yang dapat menaikkan Pendapatan Asli Daerah (PAD). Keadaan ini menimbulkan keprihatinan kalangan luas, karena justru program-program yang dibutuhkan oleh masyarakat banyak, seperti program-program pendidikan, kesehatan, tidak diberikan prioritas. Kematian ibu melahirkan, HIV/AIDS dan penyakit seksual lainnya, pelayanan kesehatan, kesehatan reproduksi remaja bukan lagi menjadi masalah di daerah perkotaan, tetapi juga merupakan isu yang semakin mencuat di daerah perdesaan yang memerlukan penanganan komprehensif (Hartono dkk, 2005).

Perubahan dari sistem yang sentralistik ke desentralisasi membawa perubahan dari pendekatan top-down ke pendekatan yang memberikan banyak kewenangan pada daerah, termasuk dalam kebijakan yang menyangkut kesehatan reproduksi dan pelayanan KB. Berkaitan dengan kebijakan kesehatan reproduksi, pemerintah pusat telah menandatangani kesepakatan ICPD Cairo 1994 dan telah mengadopsi kebijakan kesehatan reproduksi dengan menentukan lima bidang prioritas yang meliputi empat esensi dan lima kompehensif sebagaimana telah dijelaskan sebelumnya. Studi P2 Kependudukan LIPI (Situmorang dkk, 2009; Hartono dkk, 2005; Raharjo dkk, 2002) menunjukkan bahwa masing-masing daerah mempunyai kebijakan dan prioritas pembangunan masing-masing. Secara umum pemberian kewenangan pada daerah untuk menetapkan prioritas program pembangunan belum berdampak positif terhadap program kesehatan reproduksi, karena daerah yang bersangkutan belum melihatnya sebagai suatu program yang menjadi prioritas.

Tidak menjadi prioritasnya kesehatan reproduksi di daerah juga berdampak pada terbatasnya dana yang dialokasikan untuk sektor kesehatan, khususnya kesehatan reproduksi. Menurunnya kemampuan keuangan pemerintah sebagai akibat dari krisis multidimensional 1996 mengakibatkan alokasi dana pembangunan ke daerah (DAU) tidak sebesar sebagaimana yang diharapkan. Ada indikasi bahwa dengan berbagai alasan alokasi dana pembangunan daerah yang terbatas, telah terjadi penurunan pembiyaan di sektor kesehatan di banyak daerah menyusul pelaksanaan otonomi daerah. Studi tentang struktur, peran dan fungsi BKKBN paska desentralisasi yang dilakukan oleh P2 Kependudukan LIPI di 12 kabupaten/kota juga menunjukkan bahwa alokasi dana untuk program KB di daerah masih relatif kecil. Meskipun tidak dapat dipungkiri bahwa keterbatasan sumber dana yang dimiliki oleh daerah juga berpengaruh pada kecilnya alokasi dana untuk sektor kesehatan, namun dengan political will yang kuat tentunya akan dapat mengatasi permasalahan dana untuk implementasi program kesehatan reproduksi (Hartono dkk, 2005).

Berkaitan dengan hal ini, penerapan Jaminan Kesehatan Nasional sebagai bagian dari Sistem Jaminan Sosial Nasional yang dimulai sejak 2014 lalu dapat menjadi peluang meningkatkan prioritas pembangunan kesehatan, termasuk kesehatan reproduksi di daerah. Dispartisas akses dan kualitas pelayanan kesehatan yang semakin meningkat pada era otonomi daerah diharapkan dapat diminimalisir dengan kebijakan yang diharapkan dapat mencakup seluruh penduduk (universal healh coverage) selambat-lambatnya pada 2019 nanti (Mboi, 2015; Purwaningsih dkk, 2011).

\section{- Kelembagaan (institusi pelaksana) program kesehatan reproduksi}

Tantangan implementasi kesehatan reproduksi paradigma baru di Indonesia juga berkaitan erat dengan institusi (lembaga) yang terkait erat dengan 
permasalahan kesehatan reproduksi. Instansi pelaksana kebijakan dan program kesehatan reproduksi yang utama di daerah adalah sektor kesehatan dan BKKBN. Kementerian Kesehatan merupakan institusi yang bertanggung jawab terhadap penentuan kebijakan dan strategi kesehatan nasional, termasuk di dalamnya mengenai kesehatan reproduksi. Melalui jaringan kesehatan yang dimilikinya dari mulai tingkat desa, kecamatan, kabupaten dan tingkat provinsi, lembaga ini memberikan pelayanan langsung terhadap masyarakat. Namun demikian, kesehatan reproduksi paradigma baru yang antara lain mendorong keterpaduan pelayanan dan program belum terlihat di sektor kesehatan. Permasalahan KIA, KB, kesehatan reproduksi remaja, IMS dan HIV/AIDS ditangani oleh unit yang berbeda-beda (terkotak-kotak) yang terkadang menimbulkan kendala dalam hal koordinasi dan integrasi program (Hartono dkk, 2005; Raharjo dkk, 2002).

BKKBN telah dikenal secara international akan kapasitas dan kemampuannya untuk melaksanakan mobilisasi masyarakat dan kegiatan penyebaran informasi melalui penyuluhan dan konseling. Bila dilihat dari tugasnya, BKKBN bertanggung jawab melakukan koordinasi semua aktifitas yang berhubungan dengan $\mathrm{KB}$, baik yang dilakukan oleh lembaga pemerintah maupun yang non pemerintah. Namun dalam perjalanannya, tugas koordinator berkembang menjadi pelaksana. Selain itu pada tahun 1990-an, BKKBN melebarkan programnya dengan memasukkan kegiatan peningkatan kesejahteraan keluarga ke dalam programnya. Perluasan wewenang ini menimbulkan ketegangan dengan instansi lain, khususnya dengan Kementerian Kesehatan. Di lain pihak, Kementerian Kesehatan yang dalam pelaksanaannya memberikan pelayanan alat kontrasepsi kepada masyarakat bersikap apatis karena tanggung jawab dan dana yang masuk untuk KB di monopoli oleh BKKBN. Sebagai akibatnya usaha untuk meningkatkan kualitas pelayanan KB kurang mendapat perhatian. Di satu pihak BKKBN merasa bahwa kualitas pelayanan bukan merupakan tanggung jawabnya, di pihak lain Kementerian kesehatan menganggap bahwa pelayanan KB bukan merupakan prioritas utama dalam program kesehatan.

Sementara itu, BKKKN mengalami perubahan dari instansi vertikal menjadi instansi otonomi berdasarkan Keppres Nomor 30 Tahun 2003. Studi P2 Kependudukan LIPI (Hartono dkk, 2005) menunjukkan kondisi pada awal desentralisasi program KB, sebagian besar (70,7 persen) BKKBN yang ada di kabupaten/kota tersebut digabungkan dengan dinas/badan dari berbagai sektor yang ada di daerah. Perubahan struktur organisasi BKKBN yang ada di kabupaten/kota ini berpengaruh terhadap penurunan kinerja para pengelola dan petugas lapangan instansi pengelola $\mathrm{KB}$ di daerah. Tidak hanya SDM, desentralisasi BKKBN juga mempengaruhi kurangnya keberlanjutan program-program seperti peningkatan usia kawin serta pendekatan program dengan melibatkan elemen penting dalam masyarakat, termasuk tokoh agama. Menurunnya kinerja pengelola ini telah berdampak pada rendahnya komitmen pemerintah daerah dalam memberikan dukungan dana bagi program KB. Rendahnya komitmen pemerintah daerah, baik komitmen politik maupun pendanaan di masa datang menjadi tantangan yang cukup besar dalam mengembangkan kebijakan kesehatan reproduksi. Di lain pihak, pemasalahan kesehatan reproduksi, termasuk KB di berbagai daerah semakin kompleks dan menuntut penanganan yang lebih serius. Selain sektor kesehatan dan BKKBN, masih banyaknya instansi/lembaga yang terkait dengan implementasi kesehatan reproduksi paradigma baru di Indonesia. Sektor-sektor terkait lainnya termasuk: Pendidikan, Sosial, Agama, Pemberdayaan Perempuan dan Anak, serta Pemuda dan Olah Raga. Mengingat luasnya cakupan permasalahan bidang kesehatan reproduksi diperlukan keterlibatan berbagai sektor dalam penanganannya. Pembentukan Komisi Nasional Kesehatan Reproduksi melalui Surat Keputusan Menteri Kesehatan Republik Indonesia Nomor 433 Tahun 1998 ditujukan untuk menangani program kesehatan reproduksi secara lintas sektoral. Pada kenyataannya tidak semudah yang diharapkan, dalam pelaksanaannya masih terdapat kesan adanya ego dari masing-masing sektor. Integrasi berbagai bidang terkait dengan kesehatan reproduksi belum berlangsung sebagaimana mestinya. Ada beberapa program yang tumpang tindih namun tidak jarang dijumpai pula beberapa program justru terkotak-kotak dan bahkan saling tidak berkaitan. Di samping itu, ada kesan kurang proaktif dari beberapa sektor yang diberi tanggung jawab. Tanggung jawab penanganan permasalahan kesehatan reproduksi yang dianggap berkaitan erat dengan rendahnya hak-hak kesehatan reproduksi perempuan dan ketimpangan gender tidak sepenuhnya ada pada kementerian terkait. Hal ini cenderung menimbulkan stagnasi yang berakibat kelambatan dalam menangani permasalahan kesehatan reproduksi.

\section{PELAYANAN KESEHATAN REPRODUKSI ESENSIAL (PKRE) TERPADU DI PUSKESMAS: LESSON LEARNED DAN TANTANGAN KEBERLANJUTAN PROGRAM}

Banyak tantangan yang dihadapi berkaitan dengan penerapan kebijakan kesehatan reproduksi paradigma 
baru di era otonomi daerah di Indonesia. Namun demikian, sebagian pengalaman di daerah menunjukkan adanya peluang implementasi yang baik. Hasil kajian P2 Kependudukan LIPI (Situmorang dkk, 2007), misalnya, menunjukkan bahwa pelaksanaan PKRE Terpadu di Puskesmas berdampak positif pada peningkatan cakupan dan kualitas pelayanan, peningkatan pemenuhan hak dan kepuasan klien, serta peningkatan pemanfaatan data dan informasi. Berkaitan dengan program ini, sejalan dengan hasil konsensus di Cairo, pemerintah Indonesia -melalui Kementerian Kesehatan- mengembangkan program pelayanan kesehatan reproduksi esensial dengan memperkenalkan PKRE Terpadu di tingkat pelayanan dasar (Puskesmas). ${ }^{2}$ Di dalam Strategi Nasional Kesehatan Reproduksi, secara eksplisit dinyatakan bahwa PKRE Terpadu harus dilaksanakan di semua Puskesmas. Pada dasarnya, program PKRE Terpadu bukan suatu program pelayanan yang baru maupun yang berdiri sendiri, tetapi merupakan keterpaduan berbagai pelayanan dari program yang terkait yang pada dasarnya sudah tersedia di tingkat pelayanan dasar (Departemen Kesehatan RI, 2005).

Pelaksanaan PKRE Terpadu memperluas jangkauan dan cakupan pelayanan Puskesmas termasuk IMS, Klinik Remaja dan konseling. Dengan memperluas pelayanan, Puskesmas mampu menjangkau penduduk yang belum tersentuh seperti remaja melalui penyediaan program-program peduli remaja. Semua Puskesmas PKRE Terpadu yang dikaji telah mempunyai program remaja dan sebagian besar telah mempunyai ruangan khusus untuk Klinik Remaja. Hal ini telah meningkatkan keterlibatan remaja, baik dalam program-program pendidikan sebaya maupun kesadaran untuk memelihara kondisi kesehatan reproduksinya.

\footnotetext{
${ }^{2}$ Konsep dan pedoman tentang kesehatan reproduksi sejak tahun 2000 telah disosialisasikan ke seluruh provinsi dengan harapan dapat diimplementasikan melalui sumber dana di masing-masing provinsi/ kabupaten/kota. Dengan bantuan dana dari UNFPA dalam Country Program siklus ke-6 (2001-2005), uji coba implementasi program PKRE Terpadu telah dilaksanakan sejak tahun 2001 di empat provinsi, yaitu Jawa Barat, Kalimantan Barat, Nusa Tenggara Timur dan Sumatera Selatan. Program yang dilakukan termasuk upaya advokasi guna meningkatkan dukungan para pengambil keputusan pada semua tingkatan terhadap permasalahan kependudukan dan pembangunan, khususnya kesehatan reproduksi remaja, HIV/AIDS, kesetaraan dan keadilan jender, dan penghapusan kekerasan terhadap perempuan. Kerjasama ini kemudian dilanjutkan pada Country Program siklus ke-7 (2006-2010) yang mencakup enam provinsi, yaitu Jawa Barat, Kalimantan Barat, Nusa Tenggara Timur, Sumatera Selatan, Nusa Tenggara Barat dan Nangroe Aceh Darussalam (Situmorang dkk, 2007).
}

Pelaksanaan PKRE Terpadu juga berdampak pada peningkatan kualitas pelayanan. Bagi petugas kesehatan, pelaksanaan PKRE Terpadu telah memotivasi mereka untuk menggali informasi sebanyak mungkin dari kliennya, sehingga mampu mendiagnosis penyakit dan memberikan pengobatan yang lebih baik. Pelayanan konseling dan sikap proaktif dari petugas kesehatan dalam melakukan anamnesis telah meningkatkan pelayanan kesehatan menjadi lebih berkualitas dan sesuai dengan kebutuhan klien. Hak-hak individu untuk memperoleh pelayanan kesehatan reproduksi yang komprehensif dan berkualitas akan sulit terpenuhi apabila mereka tidak mengetahui bahwa mereka mempunyai masalah yang berhubungan dengan organ reproduksinya.

Perubahan mekanisme pelayanan pada Puskesmas PKRE Terpadu dari sebelumnya pelayanan terpisahpisah menjadi pelayanan terpadu juga telah meningkatkan kepuasan klien terhadap pelayanan maupun petugas kesehatan dalam memberikan pelayanan. Kepuasan klien terhadap pelayanan tersebut telah berdampak pada meningkatnya kesadaran penduduk untuk secara rutin memeriksakan kondisi kesehatan reproduksinya. Tersedianya klinik khusus remaja yang sesuai dengan karakteristik remaja telah memberikan dampak positif pada keinginan (hak) remaja untuk berkonsultasi dan memeriksakan kondisi kesehatan reproduksinya di Puskesmas. Sikap diskriminatif petugas kesehatan dalam memberikan pelayanan juga telah berubah. PKRE Terpadu juga menghilangkan stigma negatif para petugas kesehatan terhadap remaja belum menikah yang mempunyai masalah kesehatan reproduksi maupun terhadap klien yang terkena IMS.

Selain itu pelaksanaan PKRE Terpadu juga telah meningkatkan sistem pencatatan dan pelaporan data. Petugas Puskesmas menjadi lebih paham terhadap kaitan antarkomponen dalam PKRE dan pentingnya data serta informasi berkaitan dengan pelayanan. Meskipun agak bervariasi, pelayanan yang lebih lengkap dan terpadu tercermin dari informasi yang tersedia di semua Puskesmas PKRE terpadu. Dampak lain dari pelaksanaan PKRE terpadu adalah kesadaran petugas kesehatan terhadap pentingnya data pendukung, terutama yang berkaitan dengan kondisi sosial-demografi penduduk yang menjadi sasaran program.

Meskipun hasil kajian menunjukkan dampak PKRE Terpadu terhadap pelayanan puskesmas, keberlanjutan program tersebut menghadapi permasalahan tersendiri. Kisah sukses implementasi PKRE Terpadu di puskesmas-puskesmas binaan pada tahap uji coba tersebut belum bisa diimplementasikan di wilayah 
lainnya. Komitmen untuk menjadikan PKRE Terpadu sebagai program nasional belum dapat diwujudkan, demikian juga komitmen stakeholders di tingkat daerah cenderung menurun setelah uji coba PKRE Terpadu selesai dilaksanakan.

\section{KESIMPULAN}

Implementasi kebijakan kesehatan reproduksi paradigma baru di Indonesia sebagai bagian dari ratifikasi kesepakatan ICPD 1994 belum berjalan sebagaimana yang diharapkan. Proses reformasi yang diikuti dengan penerapaan kebijakan otonomi daerah pada tahun 2000-an sebenarnya sejalan dengan implementasi kesehatan reproduksi paradigma baru tersebut, yakni sama-sama mempunyai nuansa demokratisasi, hak asasi, dan juga bertujuan meningkatkan pembangunan kesehatan dan kependudukan secara lebih efektif dan efisien. Namun demikian, tidak dapat dipungkiri bahwa berbagai tantangan dihadapi berkaitan dengan adopsi kesehatan reproduksi paradigma baru, terutama di tingkat daerah (kabupaten/kota). Hal ini dikarenakan kesehatan reproduksi bukan semata-mata permasalahan kesehatan, tetapi juga erat kaitannya dengan berbagai aspek lainnya, termasuk sosial, budaya, politik, dan agama. Tantangan-tantangan tersebut termasuk: belum komprehensifnya pemahaman stakeholders terkait kesehatan reproduksi paradigma baru, belum menjadi prioritasnya permasalahan kesehatan reproduksi di daerah, belum sinerginya kemitraan (lintas program, lintas sektor, serta antara pemerintah dan masyarakat madani), serta belum kondusifnya berbagai piranti legal terkait permasalahan kesehatan reproduksi di Indonesia.

Tulisan ini merekomendasikan perlunya upaya memadukan kembali kebijakan kepro paradigma baru di tingkat global, nasional, dan daerah. Stakeholders terkait di tingkat nasional dan daerah perlu mensinergikan kembali kebijakan kesehatan reproduksi dan implementasinya dengan mempertimbangkan berbagai tantangan yang dihadapi. Agar program kesehatan reproduksi mendapatkan porsi prioritas yang layak dalam penganggaran daerah, diperlukan upaya advokasi kepada semua pihak, baik eksekutif, legislatif maupun masyarakat madani, guna meningkatkan pemahaman mereka akan pentingnya program kesehatan reproduksi paradigma baru. Upaya advokasi ini perlu didukung dengan tersedianya data kondisi kesehatan reproduksi yang akurat sebagai bahan bagi para penentu kebijakan daerah. Tersedianya data kesehatan reproduksi yang memadai tersebut sekaligus dapat menjadi indikator monitoring dan evaluasi keberhasilan pembangunan kesehatan dan kependudukan di masing-masing daerah.

\section{DAFTAR PUSTAKA}

Badan Kependudukan dan Keluarga Berencana Nasional (BKKBN). 2013. Profil Kependudukan dan Pembangunan di Indonesia Tahun 2013. Jakarta: BKKBN.

Badan Penelitian dan Pengembangan Kesehatan Kementerian Kesehatan Republik Indonesia. 2013. Riset Kesehatan Dasar 2013. Jakarta: Kementerian Kesehatan.

Badan Pusat Statistik. 2010. Sensus Penduduk 2010. Jakarta: Badan Pusat Statistik.

Departemen Kesehatan RI, Kementerian Negara Pemberdayaan Perempuan RI, Departemen Pendidikan Nasional RI, Departemen Sosial RI, Badan Koordinasi Keluarga Berencana Nasional bekerja sama dengan UNFPA. 2005. Kebijakan dan Strategi Nasional Kesehatan Reproduksi di Indonesia. Jakarta: Departemen Kesehatan RI.

Diop, I., Ba, B., Sow, K., Mbaye, A.Z., Camara, O., Ndiaye, A., Diallo, O., \& Mody, P. 2000. Implications of Decentralization for Reproductive Health Planning in Senegal. Policy Matters, No. 3, January 2000.

Hartono, D., Purwaningsih, S.S., Widayatun, Ngadi, \& Fatoni, Z. 2005. Kesehatan reproduksi dan otonomi daerah: Pembelajaran tentang penyusunan kebijakan dan perencanaan program. Jakarta: Pusat Penelitian Kependudukan LIPI.

Hartono, D., Purwaningsih, S.S., Widayatun, Handayani, T., Latifa, A., \& Fatoni, Z. 2005. System analysis of $B K K B N$ 's new role, function, and structure under the decentralized system. Jakarta: Pusat Penelitian Kependudukan LIPI bekerja sama dengan UNFPAIndonesia dan BKKBN.

Kementerian Perencanaan Pembangunan Nasional/Badan Perencanaan Pembangunan Nasional (Bappenas). 2012. Laporan Pencapaian Tujuan Pembangunan Milenium di Indonesia 2011. Jakarta: Kementerian Perencanaan Pembangunan Nasional/ Bappenas.

Kompas. 2014. Perlindungan Anak: Nikah Dini, Lingkaran Setan Kemiskinan. Kompas, 19 November 2014.

Mboi, N. 2015. Indonesia: On the Way to Universal Health Care. Health System \& Reform, 1:2, 91-97.

Pemerintah RI. 1974. UU Nomor 1 Tahun 1974 tentang Perkawinan. Jakarta: Pemerintah RI.

Pemerintah RI. 2009. UU Nomor 52 Tahun 2009 tentang Kependudukan dan Kesejahteraan Keluarga. Jakarta: Pemerintah RI.

Pemerintah RI. 2014. PP Nomor 61 Tahun 2014 tentang Kesehatan Reproduksi. Jakarta: Pemerintah RI. 
Purwaningsih, S.S., Latifa, A., Fitranita, \& Hartono, D. 2011. Kemiskinan dan Pelayanan Kesehatan dari Perspektif Kependudukan: Pengembangan Model Pelayanan Kesehatan bagi 'the Unreached'. Jakarta: P2 Kependudukan LIPI.

Pusat Studi Kependudukan dan Kebijakan UGM. 2013. Isu kehamilan remaja, tantangan bagi Indonesia. Diakses dari http://www.cpps.or.id/content/isukehamilan-remaja-tantangan-bagi-indonesia tanggal 10 November 2014.

Raharjo, Y., Situmorang, A., Hartono, D., Purwaningsih, S.S., \& Widayatun. 2002. Kesehatan reproduksi dan gender di Kabupaten Sidoarjo, Jawa Timur dan Kabupaten Timor Tengah Selatan, Nusa Tenggara Timur. Jakarta: Pusat Penelitian Kependudukan LIPI.

Shalev, C. 1998. Rights to sexual and reproductive Healththe ICPD and the Convention on the Elimination of All Forms of Discrimination Against Women. Paper presented at the International Conference on Reproductive Health, Mumbai (India), 15-19 March 1998, jointly organized by the Indian Society for the Study of Reprodction and Fertility and the UNDP/UNFPA/WHO/World Bank Special Programme of Research, Development and Research Training in Human Reproduction.

Shewprasad, S. dan Habsjah, A. 2014. Indonesia: The ICPD+20 and the Unfinished Agenda. Jakarta: BKKBN and UNFPA Indonesia Country Office.
Situmorang, A., Widayatun, Purwaningsih, S.S., Fatoni, Z., \& Astuti, Y. 2007. Implementation of Integrated Essential Reproductive Health (IERH) services in the primary health care. Jakarta, Indonesia: Pusat Penelitian Kependudukan LIPI bekerja sama dengan UNFPA-Indonesia, Kementerian Kesehatan, dan Badan Pusat Statistik.

Situmorang, A., Purwaningsih, S.S., Widayatun, \& Fatoni, Z. 2009. Fenomena IMS termasuk HIV/AIDS di Kota Batam: Alternatif kebijakan dan program penanggulangan. Jakarta,: Pusat Penelitian Kependudukan LIPI.

Susanto, C.E. 2013. Fenomena kehamilan usia remaja meningkat. Media Indonesia, 23 Mei 2013. Diakses dari http://www.mediaindonesia.com pada 10 November 2014.

United Nations Development Programme (UNDP). 2011. A Social Determinants Approach to Maternal Health. Roles for Development Actors. Discussion Paper.

United Nations (UN). 1995. Report of the International Conference on Population and Development, Cairo, 5-13 September 1994. New York, USA: United Nations.

Utomo, I. D., McDonald, P., Reimondos, A., Hull, T., Utomo, A. 2012. The 2010 Greater Jakarta Transition to Adulthood Study. Policy Brief No. 5 Pelayanan Kesehatan Reproduksi untuk penduduk Dewasa Muda Lajang.

Wahyuni, D. dan Rahmadewi. 2011. Kajian Profil Penduduk Remaja (10-24 Tahun): Ada Apa dengan Remaja? Policy Brief Pusat Penelitian dan Pengembangan Kependudukan - BKKBN, Seri I, No. 6/PusduBKKBN/Desember 2011. 